\title{
Role of Biofilms in Children with Chronic Adenoiditis and Middle Ear Disease
}

\author{
Sara Torretta ${ }^{1,2, * \mathbb{C}}$, Lorenzo Drago ${ }^{3,4} \mathbb{D}^{\mathbb{D}}$, Paola Marchisio ${ }^{1,5} \mathbb{D}^{-}$, Tullio Ibba ${ }^{1}$ and \\ Lorenzo Pignataro ${ }^{1,2}$ \\ 1 Fondazione IRCCS Ca' Granda Ospedale Maggiore Policlinico, Policlinico of Milan, Via Francesco Sforza, 35, \\ 20122 Milano, Italy; paola.marchisio@unimi.it (P.M.); Tullio.ibba@policlinico.mi.it (T.I.); \\ lorenzo.pignataro@unimi.it (L.P.) \\ 2 Department of Clinical Sciences and Community Health, University of Milan, 20122 Milan, Italy \\ 3 Clinical Chemistry and Microbiology Laboratory, IRCCS Galeazzi Institute and LITA Clinical Microbiology \\ Laboratory, 20161 Milano, Italy; lorenzo.drago@unimi.it \\ 4 Department of Clinical Science, University of Milan, 20122 Milan, Italy \\ 5 Department of Pathophysiology and Transplantation, University of Milan, 20122 Milan, Italy \\ * Correspondence: sara.torretta@unimi.it; Tel.: +39-02-5503-2563
}

Received: 21 March 2019; Accepted: 10 May 2019; Published: 13 May 2019

check for updates

\begin{abstract}
Chronic adenoiditis occurs frequently in children, and it is complicated by the subsequent development of recurrent or chronic middle ear diseases, such as recurrent acute otitis media, persistent otitis media with effusion and chronic otitis media, which may predispose a child to long-term functional sequalae and auditory impairment. Children with chronic adenoidal disease who fail to respond to traditional antibiotic therapy are usually candidates for surgery under general anaesthesia. It has been suggested that the ineffectiveness of antibiotic therapy in children with chronic adenoiditis is partially related to nasopharyngeal bacterial biofilms, which play a role in the development of chronic nasopharyngeal inflammation due to chronic adenoiditis, which is possibly associated with chronic or recurrent middle ear disease. This paper reviews the current evidence concerning the involvement of bacterial biofilms in the development of chronic adenoiditis and related middle ear infections in children.
\end{abstract}

Keywords: Biofilm; adenoids; nasopharynx; upper respiratory tract infections; otitis

\section{Introduction}

Chronic adenoiditis is frequent in children, mainly affecting those aged 3-7 years [1]. The adenoidal pads are located at the dome of the nasopharynx, and the enlargement of lymphoid tissue during childhood may contribute to the development of repeated nasopharyngeal infections, sleep disorders or middle ear infections after Eustachian tube orifice obstruction [2].

Bacterial biofilms may be involved in the pathogenesis of chronic adenoiditis, as they may be present throughout the nasopharyngeal mucosa, and particularly in the lateral portion of adenoidal pads extending towards the orifice of the Eustachian tube.

Given the close anatomical and functional relationship between the nasopharynx and the middle ear (adenoidal pads may laterally extend to the ostium of the Eustachian tube), chronic adenoiditis is often complicated by the development of chronic or recurrent middle ear disease [3-5], which may manifest itself as persistent serous or mucous fluid in the middle ear (chronic otitis media with effusion, OME), repeated acute middle ear infections (recurrent acute otitis media, RAOM), or long-lasting middle ear suppuration through chronic perforation of the tympanic membrane (chronic suppurative otitis media, CSOM) [3-5]. Chronic OME is defined as documented as middle ear effusion without any 
sign of concomitant acute middle ear inflammation persisting for at least three months [4]; RAOM is defined as at least three episodes of acute otitis media within a period of six months, or more than four episodes in a period of 12 months [3]; and CSOM is defined as the presence of a long-lasting purulent ear discharge through a persistent perforation of the tympanic membrane [5]. Each of these conditions may significantly affect a patient's quality of life and possibly predispose them to long-term functional sequelae and serious complications such as mastoiditis, meningitis, cerebral abscess, and lateral sinus thrombosis and auditory impairment [5]. A better understanding of the pathogenic mechanisms underlying these diseases would help to reduce their incidence and their related complications.

The bacteria mainly involved in the pathogenesis of acute and recurrent otitis media are the so-called otopathogens-Haemophilus influenzae, Moraxella catarrhalis and Streptococcus pneumoniae-but Staphylococcus aureus may also be involved, albeit less frequently [6,7]. Chronic otitis media is generally sustained by non-typeable Haemophilus influenzae, Pseudomonas aeruginosa and Staphylococcus aureus [8], and chronic nasopharyngitis and adenoiditis are due to the otopathogens Staphylococcus aureus, Pseudomonas aeruginosa and Haemophilus parainfluenzae [9].

It has been suggested that the lack of response to antibiotic therapy in children with chronic adenoiditis is partially attributable to the presence of nasopharyngeal bacterial biofilms, which may play a pathogenic role in the development of chronic nasopharyngeal inflammation due to chronic adenoiditis and are possibly associated with chronic or recurrent middle ear disease [9-13]. The failure of traditional antibiotic treatment is related to the resistance of bacterial biofilm, which is partially due to the physical barrier formed by the extracellular matrix, which blocks antibiotic diffusion within the biofilm, as well as some particular characteristics of the biofilms themselves [10], such as reduced bacterial replication in the inner layers and resistance mechanisms acquired as a result of the quorum-sensing process. Although various alternative conservative treatments have been tested (including manuka honey, baby shampoo, and hyaluronic acid- or acetylcysteine-based topical treatments), there is no evidence that they are effective in vivo.

Given the largely ineffective nature of traditional antibiotic therapy, children with chronic adenoiditis (with or without middle ear involvement) are generally candidates for surgical treatment under general anaesthesia, including adenoidectomy and myringotomy, with or without the placement of a ventilation tube [14]. However, although the definitive treatment is surgical debridement, no clinical studies have investigated possible post-surgical changes in nasopharyngeal and middle ear biofilms.

This paper discusses current evidence concerning the involvement of bacterial biofilms in chronic adenoiditis and recurrent or chronic middle ear infections in children: English language papers concerning the possible role of bacterial biofilms in chronic adenoidal and middle ear disease that were published between 1 January 2007 and 1 January 2019 were selected after a MEDLINE search (accessed via PubMed). Separate systematic literature searches were made for chronic adenoiditis and middle ear disease (i.e., OME, RAOM and CSOM). Consideration was only given to fully accessible, original in vivo studies $[9,11,12,15-31]$ published in peer-reviewed journals that specifically concerned the role of bacterial biofilm in chronic adenoiditis and recurrent/chronic middle ear disease in children. In vitro, ex vivo and animal studies, reviews and papers that did not clearly report the prevalence of bacterial biofilm involvement in their case series were excluded.

\section{Bacterial Biofilms in Chronic Adenoiditis and Sampling Procedures}

The literature search used the following terms: "biofilm AND nasopharyngitis", "biofilm AND nasopharynx", "biofilm AND adenoid", and "biofilm AND adenoiditis". This review was based on eight $[9,11,12,15-19]$ of the 37 initially identified papers concerning chronic adenoiditis and included a total of 496 paediatric patients (Figure 1). 


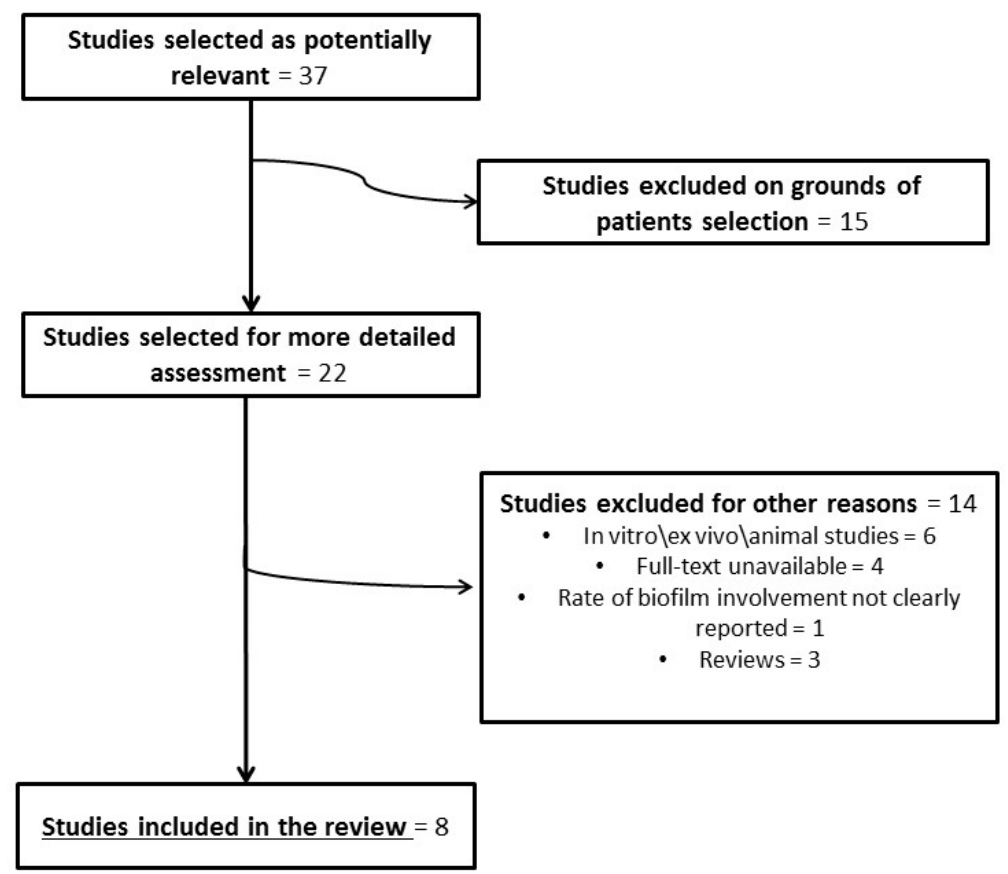

Figure 1. Flowchart of article selection (biofilms in chronic adenoiditis).

The microbiological analyses of adenoid biopsies (collected during surgery) and nasopharyngeal swabs were made by means of spectrophotometry or other advanced microbiological techniques (scanning electron microscopy, fluorescence in situ hybridisation).

Analysis of the currently available literature suggests that the adenoids and surrounding nasopharyngeal mucosa are frequently covered by polymicrobial biofilm, and thus possibly act as an infectious focus in some cases. Bacterial biofilm can be found in up to $100 \%$ of nasopharyngeal samples taken from children with chronic nasopharyngeal infections. However, the reported prevalence rate varies widely $(41 \%-100 \%)$ (Table 1 ) depending on the case series and the sampling and microbiological analysis techniques used $[9,11,12,15-19]$. The main bacteria involved were shown to be the otopathogens (M. catarrhalis, H. influenzae, S. pneumoniae), S. pyogenes, S. aureus and P. aeruginosa. Table 1 shows the main characteristics of the selected case series and the related microbiological findings.

The microbiological analyses of nasopharyngeal specimens, which generally used spectrophotometry, scanning electron microscopy or fluorescence in situ hybridisation, showed that the main bacteria involved in nasopharyngeal biofilm production are the otopathogens (H. influenzae, M. catarrhalis and S. pneumoniae) [9-13], which are also responsible for middle ear infections.

The spectrophotometric method requires the incubation of bacterial cultures with appropriate growth medium in order to ensure biofilm development, after which the growth medium is discarded, each well is washed to eliminate any unbound bacteria, the adherent organisms are stained with crystal violet and any excess stain is rinsed away. Once the plates have been dried, the optical densities (ODs) of the stained adherent bacterial biofilms are measured using a microplate reader in order to assess bacterial adherence and biofilm formation [9].

Scanning electron microscopy of adenoidal specimens follows the method used by Hoa et al. [32]: the tissue samples are fixed, washed, dehydrated and coated for final imaging preparation and then imaged at a resolution of $1000 \times$ in order to study the biofilm architecture and analyse it using dedicated image analysis software.

The fluorescence in situ hybridisation of adenoidal samples with pathogen-specific 16S rRNA probes was described by Hoa et al. [32] as follows: specimens are fixed, washed and incubated, and then probed for H. influenzae, S. pneumoniae, M. catarrhalis and S. aureus, or using a universal eubacterial $16 \mathrm{~S}$ rRNA probe. 
Table 1. Main characteristics and related microbiological findings of the main studies of bacterial biofilm in chronic adenoiditis.

\begin{tabular}{|c|c|c|c|c|c|}
\hline Authors; Year & $\begin{array}{l}\text { No. of Patients; } \\
\text { Samples }\end{array}$ & $\begin{array}{c}\text { Mean Age } \pm \text { SD, } \\
\text { years }\end{array}$ & Analytical Technique & $\begin{array}{c}\text { Prevalence of Bacterial } \\
\text { Biofilm (\%) }\end{array}$ & Prevalence of Isolated BPB \\
\hline Galli et al. [15], 2007 & $15 ; 15$ & - & SEM & 100 & $\begin{array}{l}\text { H. influenzae }=67 \% \\
\text { S. pyogenese }=7 \% \\
\text { Alpha-hemolytic streptococcus i }=13 \%\end{array}$ \\
\hline Al-Mazrou et al. [16], 2008 & $\begin{array}{c}76 ; 76 \text { (adenoids and } \\
\text { tonsils) }\end{array}$ & $5.7 \pm 3.3$ & SEM & 85 & Staphylococcus spp. and Streptococcus spp. \\
\hline Winther et al. [17], 2009 & $-; 9$ & - & $\begin{array}{c}\text { PAS of Carnoy fluid and } \\
\text { FISH }\end{array}$ & 91 & - \\
\hline Torretta et al. [9], 2011 & $42 ; 84$ & $7.0 \pm 2.7$ & Spectrophotometry & BPB in 74 NPS and 69 B & $\begin{array}{l}\text { S. aureus }=55 \% \text { (NPS); } 79 \% \text { (B) } \\
\text { M. catarrhalis }=19 \% \text { (NPS); } 21 \% \text { (B) } \\
\text { H. influenzae }=10 \% \text { (NPS); } 14 \% \text { (B) } \\
\text { S. pneumoniae }=35 \% \text { (NPS); } 10 \% \text { (B) } \\
\text { P. aeruginosa }=3 \% \text { (NPS); } 10 \% \text { (B) } \\
\text { S. pyogenes }=10 \% \text { (NPS); } 7 \% \text { (B) } \\
\text { H. parainfluenzae = 23\% (NPS); } 0 \% \text { (B) }\end{array}$ \\
\hline Torretta et al. [12], 2012 & $113 ;-$ & $\begin{array}{l}\text { Median: } 40 \text { (range: } \\
\text { 10-132), months }\end{array}$ & Spectrophotometry & $\begin{array}{l}\mathrm{BPO} \text { in } 41 \text { patients with } \\
\text { recurrent middle ear } \\
\text { infections and } 14 \text { controls }\end{array}$ & $\begin{array}{l}\text { M. catarrhalis }=6 \text { (patients); } 34 \text { (controls) } \\
\text { S. pneumoniae }=17 \text { (patients); } 33 \text { (controls) } \\
\text { S. pyogenes }=6 \text { (patients); } 33 \text { (controls) } \\
\text { H. influenzae }=71 \text { (patients); } 0 \text { (controls) }\end{array}$ \\
\hline Torretta et al. [11], 2013 & $45 ; 135$ & $\begin{array}{l}\text { Median: } 7 \text { (range: } \\
4-13 \text { ) }\end{array}$ & Spectrophotometry & $\mathrm{BPB}$ in $72(\mathrm{ET}) ; 53$ (NPD) & $\begin{array}{l}\text { S. aureus }=45 \%(\mathrm{ET}) ; 50 \%(\mathrm{NPD}) \\
\text { S. pneumoniae }=18 \%(\mathrm{ET}) ; 12 \%(\mathrm{NPD}) \\
\text { M. catarrhalis }=20 \%(\mathrm{ET}) ; 12 \%(\mathrm{NPD}) \\
\text { S. pyogenes }=9 \%(\mathrm{ET}) ; 9 \%(\mathrm{NPD}) \\
\text { H. influenzae }=3 \%(\mathrm{ET}) ; 4 \%(\mathrm{NPD}) \\
\text { Coagulase negative staphylococci }=3 \%(\mathrm{ET}) \\
4 \%(\mathrm{NPD}) \\
\text { H. parainfluenzae }=1 \%(\mathrm{ET}) ; 4 \%(\mathrm{NPD}) \\
\text { P. fluorescens }=1 \%(\mathrm{ET}) ; 4 \%(\mathrm{NPD})\end{array}$ \\
\hline $\begin{array}{c}\text { Kosikowska et al. [18], } \\
2015\end{array}$ & $164 ; 328$ & Range: $2-5$ & Spectrophotometry & $\begin{array}{c}\text { BP Haemophilus species in } \\
97 \% \text { of patients. }\end{array}$ & $\begin{array}{l}67 \% \text { of } H \text {. influenzae samples were biofilm } \\
\text { producers } \\
56 \% \text { of } H \text {. parainfluenzae samples were } \\
\text { biofilm producers } \\
86 \% \text { of other } H . \text { spp samples were biofilm } \\
\text { producers }\end{array}$ \\
\hline Tsou et al. [19], 2015 & $32 ;-$ & Range: 4-13 & $\begin{array}{l}\text { Scanning electron } \\
\text { microscopy }\end{array}$ & $\begin{array}{l}\text { BP } \beta \text {-lactam-resistant Haen } \\
\text { detected in children with c } \\
\text { hypertrophy without infec }\end{array}$ & $\begin{array}{l}\text { philus influenzae type b more frequently } \\
\text { ronic adenoiditis than in those with adenoidal } \\
\text { ons. }\end{array}$ \\
\hline
\end{tabular}

SD: standard deviation; B: biopsy; NPS: nasopharyngeal swab; SEM: scanning electron microscopy; PAS: periodic acid-Schiff stain; FISH: fluorescence in situ hybridisation; BPB: biofilm-producing bacteria; BPO: biofilm-producing otopathogens; BP: biofilm-producing; ET: near the Eustachian tube orifice; NPD: at the "nasopharyngeal dome" [11]. 
There is no unanimous consensus concerning the preferred sampling technique as both adenoidal biopsies and nasopharyngeal swabs have been used, although the former has led to higher rates of positive findings. The well-known resistance of biofilms to mechanical injury reduces the negative predictive value of nasopharyngeal swabs in detecting biofilms [9], but the rate of adenoidal biofilm detection can also vary significantly in the case of bioptic specimens, probably because of the different methods used for fixation and histological processing. As the direction of mucociliary clearance leads to uneven biofilm distribution on the mucosal layer, the biofilm detection rate is higher in the caudal than the cephalic or middle sections [17]. Moreover, the traditional fixation method used during histological processing leads to the dispersion of sessile biofilms attached to the top of a fold on the nasopharyngeal surface, whereas the planktonic biofilm embedded in deep areas is preserved, because it is not subject to the actions of nasopharyngeal mucous flow [17].

Finally, the variability in detection rates of bacterial biofilm among patients with chronic adenoiditis may also be partially due to the different microbiological techniques used to detect them. Advanced but expensive electron microscopy techniques can more accurately evaluate the complex 3-dimensional structure of biofilm than the easier-to-use spectrophotometry technique, which can be used to quantify bacterial adhesion [9-13].

\section{Nasopharyngeal Bacterial Biofilm: Is There A Correlation between Adenoiditis and Recurrent/Chronic Middle Ear Infections?}

The literature search was based on the terms "biofilm AND otitis". Eighteen [20-31] of the 65 initially identified papers concerning recurrent/chronic middle ear disease with a total of 456 patients (Figure 2) were included.

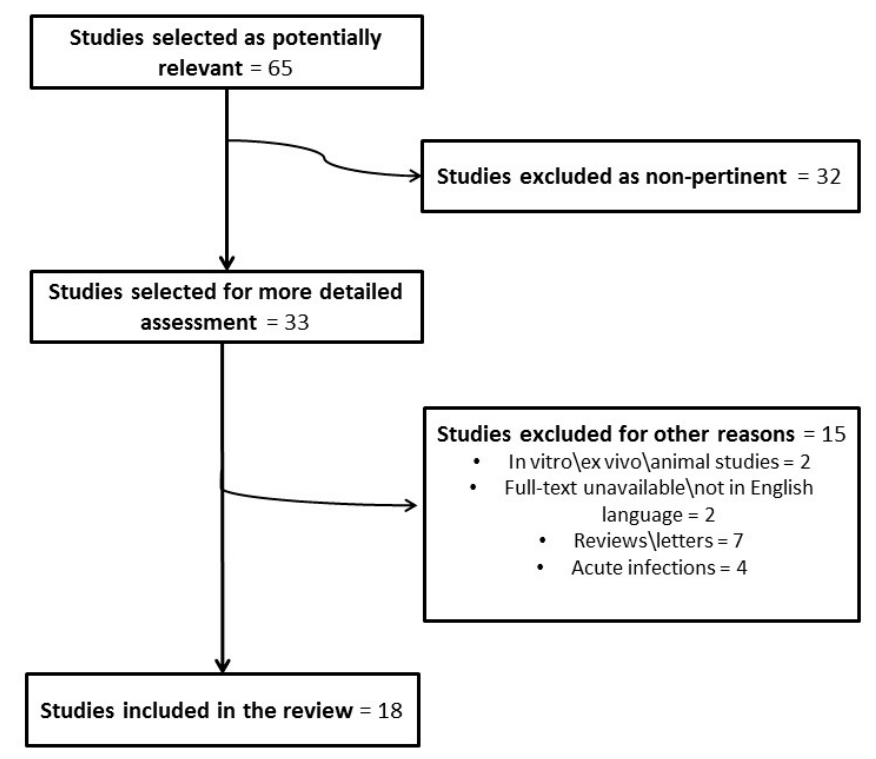

Figure 2. Flowchart of article selection (biofilms in recurrent/chronic middle ear disease).

The microbiological analyses of middle ear specimens (i.e., middle ear fluid/mucosa) conducted by spectrophotometry or other advanced microbiological techniques (scanning electron microscopy, fluorescence in situ hybridisation).

Biofilm involvement was detected in a variable proportion of patients with recurrent/chronic otitis media $(0 \%-100 \%)$, depending on the case series and type of middle ear disease investigated: in $0 \%-100 \%$ of the adenoidal and/or middle ear samples collected from patients with OME; in $70 \%-80 \%$ of those taken from patients with RAOM; and in $83 \%-100 \%$ of those taken from patients with CSOM. The main bacteria involved were those listed above. Table 2 shows the main characteristics of the selected case series and the related microbiological findings. 
Table 2. Main characteristics and related microbiological findings of the main studies of bacterial biofilm in recurrent/chronic middle ear diseases.

\begin{tabular}{|c|c|c|c|c|c|c|}
\hline Authors; Year & $\begin{array}{l}\text { No. of Patients; } \\
\text { Samples }\end{array}$ & $\begin{array}{l}\text { Mean Age } \pm \text { SD, } \\
\text { Years }\end{array}$ & Disease & $\begin{array}{l}\text { Analytical } \\
\text { Technique }\end{array}$ & $\begin{array}{c}\text { Prevalence of } \\
\text { Bacterial Biofilm (\%) }\end{array}$ & Prevalence of Isolated ВРВ \\
\hline Homoe et al. [20], 2009 & $10 ; 13$ & Range: 2-15 & $\begin{array}{l}\text { CSOM } \\
\text { OME }\end{array}$ & $\begin{array}{l}\text { Peptide nucleic } \\
\text { acid-FISH of MEM } \\
\text { and MEF }\end{array}$ & $\begin{array}{l}83 \% \\
0 \%\end{array}$ & $\begin{array}{l}\text { S. aureus }=67 \% \\
\text { S. maltophilia }=17 \%\end{array}$ \\
\hline Zuliani et al. [21], 2009 & $68 ; 68$ & $\begin{array}{l}\text { Range: } 3 \text { months-15 } \\
\text { years }\end{array}$ & $\begin{array}{c}\text { RAOM } \\
\text { OSA }\end{array}$ & $\begin{array}{l}\text { SEM of adenoidal } \\
\text { mucosa }\end{array}$ & \multicolumn{2}{|c|}{$\begin{array}{l}93 \% \text { of adenoidal mucosa covered by biofilm in children with RAOM; } 1 \% \\
\text { of adenoidal mucosa covered by biofilm in children with OSA }\end{array}$} \\
\hline Hoa et al. [22], 2010 & $30 ; 30$ & $\begin{array}{l}\text { Range: } 9 \text { months-10 } \\
\text { years }\end{array}$ & $\begin{array}{l}\text { RAOM } \\
\text { OME } \\
\text { OSA }\end{array}$ & $\begin{array}{l}\text { SEM of adenoidal } \\
\text { mucosa }\end{array}$ & \multicolumn{2}{|c|}{$\begin{array}{l}98 \% \text { of adenoidal mucosa covered by biofilm in children with RAOM; } \\
28 \% \text { of adenoidal mucosa covered by biofilm in children with OME; and } \\
<1 \% \text { of adenoidal mucosa covered by biofilm in children with OSA }\end{array}$} \\
\hline Saylam et al. [23], 2011 & $17 ; 17$ & $7.5 \pm 2.6$ & OME & $\begin{array}{l}\text { SEM of adenoidal } \\
\text { mucosa }\end{array}$ & $100 \%$ & - \\
\hline Nistico et al. [24], 2011 & $35 ;-$ & 4.1 (range: $1-10$ ) & $\begin{array}{l}\text { COM } \\
\text { OSA }\end{array}$ & $\begin{array}{l}\text { CLSM and FISH of } \\
\text { adenoidal mucosa }\end{array}$ & \multicolumn{2}{|c|}{$\begin{array}{l}\text { H. influenzae, S. pneumoniae, S. aureus polymicrobic biofilm in most } \\
\text { samples }\end{array}$} \\
\hline Daniel et al. [25], 2012 & $42 ; 62$ & $\begin{array}{l}\text { Median: } 4.5 \text { (range: } \\
1-75)\end{array}$ & OME & CLSM of MEM & $49 \%$ & $\begin{array}{l}\text { Coagulase-negative staphylococci }=3 \\
\text { S. aureus }=2 \\
\text { S. pneumoniae }=3 \\
\text { Bacillus spp. }=2 \\
\text { M. catarrhalis }=2 \\
\text { Pseudomonas spp. }=5 \\
\text { Other }=14\end{array}$ \\
\hline Saafan et al. [26], 2013 & $100 ;-$ & 5.7 (range: 3-14) & OME & $\begin{array}{l}\text { SEM and multiplex } \\
\text { PCR of adenoidal } \\
\text { mucosa and MEM }\end{array}$ & $\begin{array}{l}74 \% \text { (adenoidal } \\
\text { mucosa) }\end{array}$ & - \\
\hline Thornton et al. [27], 2013 & $24 ; 38$ & $\begin{array}{l}\text { Median: } 17.9 \text { (range: } \\
\text { 9.7-36.0) months }\end{array}$ & RAOM & FISH on MEM & $70 \%$ & $\begin{array}{l}\text { S. pneumoniae }=73 \\
\text { H. influenzae }=65 \\
\text { M. catarrhalis }=27 \\
\text { S. aureus }=27 \\
\text { P. aeruginosa }=4\end{array}$ \\
\hline Szalmas et al. [28], 2013 & $59 ;-$ & 5.1 (range: $3-11$ ) & $\begin{array}{l}\text { RAOM } \\
\text { OME } \\
\text { OSA }\end{array}$ & $\begin{array}{l}\text { Hematoxylin-eosin } \\
\text { and Gram staining of } \\
\text { adenoidal mucosa }\end{array}$ & $\begin{array}{l}80 \% \\
0 \% \\
6 \%\end{array}$ & - \\
\hline $\begin{array}{l}\text { Van Hoecke et al. [29], } \\
2016\end{array}$ & $21 ; 34$ & 3.3 (range: $1.1-6.6$ ) & OME & $\begin{array}{l}\text { FISH and CLSM of } \\
\text { MEE }\end{array}$ & $62 \%$ H. influenza biofilm & \\
\hline Tawfik et al. [30], 2016 & $40 ;-$ & Range: $1-16$ & OME & $\begin{array}{l}\text { SEM of adenoidal } \\
\text { mucosa }\end{array}$ & $100 \%$ & - \\
\hline $\begin{array}{c}\text { De la Torre et al. [31], } \\
2018\end{array}$ & $10 ; 20$ & 10 (range: 6-17) & Cholesteatoma & $\begin{array}{c}\text { CLSM of } \\
\text { cholesteatoma }\end{array}$ & $100 \%$ & - \\
\hline
\end{tabular}

SD: standard deviation; BPB: biofilm-producing bacteria; SEM: scanning electron microscopy; CLSM: confocal laser scanning microscopy; FISH: fluorescence in situ hybridisation; PCR: polymerase-chain reaction; MEM: middle ear mucosa; MEF: middle ear fluid; OME: chronic otitis media; RAOM: recurrent acute otitis media; OSA: obstructive sleep apnoea; COM: chronic otitis media (unless otherwise specified); CSOM: chronic suppurative otitis media. 
The pathogenic role of bacterial biofilms in the development of chronic adenoiditis and middle ear disease still remains controversial, as, on one hand, it is supported by the detection of biofilms in a large prevalence of samples taken from the adenoids/nasopharynx of otitis-prone children (mainly children with RAOM and CSOM) [20-26,28,30,33-41] (Table 2). On the other hand, some papers show a reduced rate of nasopharyngeal/adenoidal biofilm involvement especially in children with OME $[20,22,25,28]$. Some electron microscopy studies have documented the massive distribution of biofilm on the surface of the adenoids of otitis-prone children who are candidates for adenoidectomy [12,13], and it has been reported that more than $93 \%$ of the adenoidal surface is occupied by biofilm in children with RAOM, whereas only $1 \%$ is involved in children undergoing surgery because of sleep disordered breathing.

The prevalence of adenoidal biofilms in children with a history of severe RAOM (defined as the presence of four acute otitis media episodes within a period of six months, or six in 12 months) is higher than that in children with sleep disordered breathing related to adenoidal hypertrophy but not to a history of middle ear infections [24]. Furthermore, the role of nasopharyngeal biofilms in favouring the development of non-severe RAOM was documented by Torretta et al. [13], who found that the rate of otopathogenic biofilms in the nasopharynxes of 58 children with non-severe RAOM was higher than that found in 55 healthy controls (about $41 \%$ vs. $14 \%$ ).

It has also been found that there is a variable prevalence of otopathogenic biofilms in specimens of middle ear mucosa/fluid taken from patients with persistent middle ear infections [34]; this suggests their involvement in the pathogenesis of persistent OME, only in some cases. Although OME was once considered bacteriologically sterile because of the difficulty of detecting pathogens by means of traditional culturing methods, the use of the polymerase chain reaction has led to the detection of bacterial DNA in the middle ear fluid of patients with persistent OME [36], and more recently, the discovery of bacterial mRNA in the middle ear mucosa of patients with OME has confirmed the bacterial hypothesis by documenting the presence of replicative bacteria [37]. The role of otopathogenic biofilms colonising the middle ear in the development of persistent OME is now considered, and scanning electron microscopy or confocal laser scanning microscopy studies of middle ear samples from children with OME have reported biofilm detection rates ranging from $40 \%$ to $92 \%$ [25,37]. However, the precise relationship between nasopharyngeal biofilms and OME is still unclear, and the published findings are conflicting. Saafan et al. [26] and Saylam et al. [23] described a greater prevalence of adenoidal biofilm in children with OME than in controls, whereas Hoa et al. [22] found lower prevalence of nasopharyngeal biofilm in children with persistent OME than in children with $\operatorname{RAOM}(28 \%$ vs. $99 \%)$.

Bacterial biofilms are also thought to be involved in the pathogenesis of chronic middle ear infections as they have been found in $43 \%-92 \%$ of middle ear specimens from patients with persistent perforations of the tympanic membrane leading to chronic middle ear suppuration (CSOM) $[20,34,38,39]$ and in $75 \%-85 \%$ of specimens taken from patients with complicated disease sustained by the presence of dangerous chronic otitis media with cholesteatoma [20,33,39].

Regardless of whether otopathogenic nasopharyngeal and middle ear biofilms are involved in the development of chronic adenoiditis, RAOM or persistent OME, it is clear that the middle ear biofilms produced by S. aureus and P. aeruginosa play a pivotal role in CSOM [17] and chronic otitis media with cholesteatoma $[20,34,35,38,39]$.

Finally, Moriyama et al. [40] hypothesised that bacterial biofilms are also responsible for the development of acute otitis media on the basis of the detection of biofilms produced by clinically non-typeable $H$. influenzae in patients with acute middle ear infections. This may explain the failure of traditional antibiotic treatment to cure patients with AOM, which may be related to the fact that otopathogens can produce biofilms rapidly in favourable environments [35]. However, this theory is still debated, as a study by Mizrahi et al. [41] failed to find any significant correlation between the presence of biofilm produced by non-typeable $H$. influenza and treatment failure or infectious recurrences in patients with AOM. These findings were supported by Osgood et al. [42], who suggested that the aerobic conditions occurring during AOM episodes may limit biofilm formation. 
All of the above suggest a possible link between biofilm-related adenoiditis and chronic middle ear infections, whereas middle ear involvement is probably secondary to the colonisation of the middle ear mucosa by nasopharyngeal biofilm-producing otopathogens, which periodically spread in their planktonic forms during any acute infectious exacerbation. The subsequent migration of bacterial strains through an impaired Eustachian tube (due to the obstruction of its orifice by enlarged adenoidal pads) may lead to their adhesion to the middle ear mucosa and their subsequent sustenance of an independent chronic suppurative process whose periodic acute activation may be related to an autonomous middle ear biofilm. Despite this, given the high variability in detection rates and the fact that most previous studies did not evaluate the direct virulence of biofilm producers, no definitive conclusions about the pathogenic role of nasopharyngeal/adenoidal biofilm in the development of middle ear disease can be drawn.

\section{Topographic Distribution of Bacterial Biofilms in the Nasopharynx.}

The different distribution of bacterial biofilms on the mucosal layer of adenoidal pads was investigated by Torretta et al. [11], who collected bioptic specimens for spectrophotometric analysis from the "nasopharyngeal dome" (i.e., the upper portion of the nasopharynx) and near the Eustachian tube orifice of children who were candidates for adenoidectomy because of chronic adenoiditis and persistent or chronic middle ear infections in order to investigate whether the two sites were different in terms of the prevalence of biofilm-producing otopathogens, the type of pathogens and the biofilm production capacity [11]. Biofilm-producing bacteria were detected in about $72 \%$ of the specimens from near the Eustachian tube orifice and about $53 \%$ of the specimens from the "nasopharyngeal dome"; S. pneumoniae and M. catarrhalis were more frequently isolated near the Eustachian tube orifice, and S. aureus was more frequently found at the "nasopharyngeal dome", but the difference in strains was not statistically significant (Figure 3). However, the bacterial biofilms located near the Eustachian tube orifice were more frequently polymicrobial than those at the "nasopharyngeal dome", thus suggesting that they were also more virulent [11].

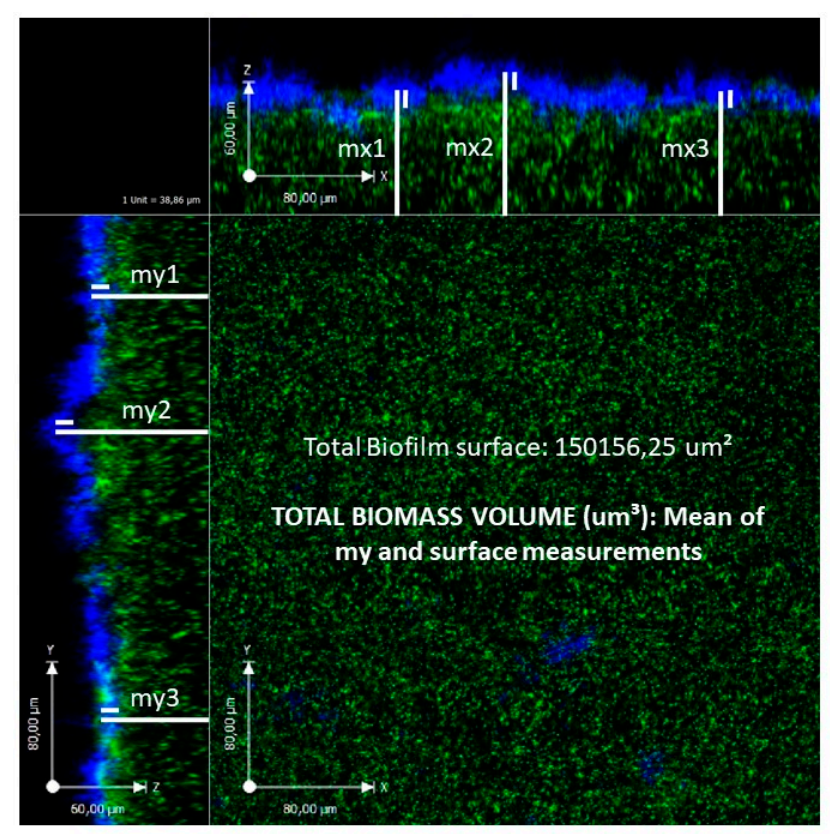

Figure 3. Total surface area of $S$. aureus biofilm after 48 hours (my $=$ thickness measurement sides) as revealed by confocal laser scanning microscopy of an adenoidal specimen.

It can therefore be speculated that chronically infected and enlarged adenoids (particularly when the adenoidal pads extend toward the Eustachian tube orifice) are sources of otopathogenic biofilms that periodically release planktonic species that are capable of colonising the Eustachian tube and then 
the middle ear mucosa. This suggests that surgical debridement during adenoidectomy needs to be as complete as possible (taking particular care to avoid any residues near the Eustachian tube orifice) in order to avoid biofilm survival in any persistent nasopharyngeal infectious focus.

It has also been reported that nasopharyngeal biofilm-producing otopathogens are more prevalent in the nasopharynxes of young children with RAOM (but not chronic adenoiditis) than in healthy controls, which suggests that nasopharyngeal biofilms are independently involved in the development of recurrent middle ear infections regardless of the presence of adenoidal hypertrophy [13], which generally affects children aged $>3$ years.

\section{Conclusions}

Taken together, the current evidence documents the large prevalence of bacterial biofilms in adenoidal and middle ear samples taken from children with chronic adenoiditis with or without middle ear disease. This finding could suggest that otopathogenic nasopharyngeal biofilm is involved in the development and perpetuation of chronic adenoiditis. Subsequently, chronic biofilm-sustained adenoiditis may act as a possible risk factor to exacerbate adenoiditis-associated middle ear infections by predisposing some patients to developing independent and recalcitrant recurrent or chronic middle ear diseases such as RAOM, CSOM, and chronic otitis media associated with cholesteatoma. The involvement of bacterial nasopharyngeal/adenoidal biofilm in OME is questionable. In addition, in most studies, it is unclear whether biofilm producers are indeed highly and potentially virulent due to as over-producing toxins, having high biological fitness and/or being highly adhesive, or whether biofilm is solely generated as a result of repeated or chronic infections, when then act as dormant cells. Therefore, no definitive conclusions about the pathogenic role of nasopharyngeal/adenoidal biofilm in the development of middle ear disease can be drawn.

Surgical debridement is still the treatment of choice for eradicating nasopharyngeal biofilms, but scientific efforts should be made to test alternative non-surgical treatment strategies.

\section{Key Concepts}

1. Chronic adenoiditis frequently occurs in paediatric patients and is often complicated by the subsequent development of recurrent or chronic middle ear diseases.

2. The adenoids and surrounding nasopharynx may be sources of otopathogenic biofilms that periodically release planktonic species that are capable of colonising middle ear mucosa through an impaired Eustachian tube, thus predisposing individuals to the development of chronic nasopharyngeal and middle ear infections.

3. The main pathogens involved in nasopharyngeal biofilm production are the so-called otopathogens (Haemophilus influenzae, Moraxella catarrhalis and Streptococcus pneumoniae).

4. Given the specific topographic distribution of nasopharyngeal biofilm on adenoidal pads, adenoids should be carefully resected in the case of chronic nasopharyngeal infection, taking particular care to avoid any residues near the ostium of the Eustachian tube in order to avoid biofilm survival in any persistent nasopharyngeal infectious focus.

5. As nasopharyngeal biofilm-producing otopathogens seem to be also involved in the development of RAOM in young children without adenoidal hypertrophy, it can be speculated that nasopharyngeal biofilms are independently involved in the development of recurrent middle ear infections, regardless of the presence of adenoidal hypertrophy.

6. Future studies should investigate the potential virulence of biofilm-producers in the adenoids of otitis-prone children.

Author Contributions: S.T. searched the literature and drafted the manuscript; P.M. helped in drafting the manuscript; L.P. and L.D. made important intellectual contributions to the paper; T.I. helped to revise the paper.

Conflicts of Interest: The authors declare they have no conflict of interest. 


\section{References}

1. Cassano, P.; Gelardi, M.; Cassano, M.; Fiorella, M.L.; Fiorella, R. Adenoid tissue rhinopharyngeal obstruction grading based on fiberendoscopic findings: A novel approach to therapeutic management. Int. J. Pediatr. Otorhinolaryngol. 2003, 67, 1303-1309. [CrossRef]

2. Marseglia, G.L.; Poddighe, D.; Caimmi, D.; Marseglia, A.; Caimmi, S.; Ciprandi, G.; Klersy, C.; Pagella, F.; Castellazzi, A.M. Role of adenoids and adenoiditis in children with allergy and otitis media. Curr. Allergy Asthma Rep. 2009, 9, 460-464. [CrossRef]

3. Gates, G.A.; Klein, J.O.; Lim, D.J.; Mogi, G.; Ogra, P.L.; Pararella, M.M.; Paradise, J.L.; Tos, M. Recent advances in otitis media. 1. Definitions, terminology, and classification of otitis media. Ann. Otol. Rhinol. Laryngol. Suppl. 2002, 188, 8-18. [PubMed]

4. American Academy of Family Physicians, American Academy of Otolaryngology-Head and Neck Surgery and American Academy of Pediatrics Subcommittee on Otitis Media With Effusion. Otitis media with effusion. Pediatrics 2004, 113, 1412-1429. [CrossRef]

5. Jensen, R.G.; Koch, A.; Homøe, P. The risk of hearing loss in a population with a high prevalence of chronic suppurative otitis media. Int. J. Pediatr. Otorhinolaryngol. 2013, 77, 1530-1535. [CrossRef]

6. Casey, J.R.; Adlowitz, D.G.; Pichichero, M.E. New patterns in the otopathogens causing acute otitis media six to eight years after introduction of pneumococcal conjugate vaccine. Pediatr. Infect. Dis. J. 2010, 29, 304-309. [CrossRef] [PubMed]

7. Pichichero, M.E.; Pichichero, C.L. Persistent acute otitis media: I. Causative pathogens. Pediatr. Infect. Dis. J. 1995, 14, 178-182. [CrossRef] [PubMed]

8. Madana, J.; Yolmo, D.; Kalaiarasi, R.; Gopalakrishnan, S.; Sujatha, S. Microbiological profile with antibiotic sensitivity pattern of cholesteatomatous chronic suppurative otitis media among children. Int. J. Pediatr. Otorhinolaryngol. 2011, 75, 1104-1108. [CrossRef]

9. Torretta, S.; Drago, L.; Marchisio, P.; Mattina, R.; Clemente, I.A.; Pignataro, L. Diagnostic accuracy of nasopharyngeal swabs in detecting biofilm-producing bacteria in chronic adenoiditis: A preliminary study. Otolaryngol. Head Neck Surg. 2011, 144, 784-788. [CrossRef]

10. Nazzari, E.; Torretta, S.; Pignataro, L.; Marchisio, P.; Esposito, S. Role of biofilm in children with recurrent upper respiratory tract infections. Eur. J. Clin. Microbiol. Infect. Dis. 2015, 34, 421-429. [CrossRef]

11. Drago, L.; Cappelletti, L.; De Vecchi, E.; Pignataro, L.; Torretta, S.; Mattina, R. Antiadhesive and antibiofilm activity of hyaluronic acid against bacteria responsible for respiratory tract infections. APMIS 2014, 122, 1013-1019. [CrossRef]

12. Torretta, S.; Drago, L.; Marchisio, P.; Gaffuri, M.; Clemente, I.A.; Pignataro, L. Topographic distribution of biofilm-producing bacteria in adenoid subsites of children with chronic or recurrent middle ear infections. Ann. Otol. Rhinol. Laryngol. 2013, 122, 109-113. [CrossRef]

13. Torretta, S.; Marchisio, P.; Drago, L.; Baggi, E.; De Vecchi, E.; Garavello, W.; Nazzari, E.; Pignataro, L.; Esposito, S. Nasopharyngeal biofilm-producing otopathogens in children with nonsevere recurrent acute otitis media. Otolaryngol. Head Neck Surg. 2012, 146, 991-996. [CrossRef]

14. Capaccio, P.; Torretta, S.; Marciante, G.A.; Marchisio, P.; Forti, S.; Pignataro, L. Endoscopic Adenoidectomy in Children With Otitis Media With Effusion and Mild Hearing Loss. Clin. Exp. Otorhinolaryngol. 2016, 9, 33-38. [CrossRef]

15. Galli, J.; Calò, L.; Ardito, F.; Imperiali, M.; Bassotti, E.; Fadda, G.; Paludetti, G. Biofilm formation by Haemophilus influenzae isolated from adeno-tonsil tissue samples, and its role in recurrent adenotonsillitis. Acta Otorhinolaryngol. Ital. 2007, 27, 134-138. [PubMed]

16. Al-Mazrou, K.A.; Al-Khattaf, A.S. Adherent biofilms in adenotonsillar diseases in children. Arch. Otolaryngol. Head Neck Surg. 2008, 134, 20-23. [CrossRef] [PubMed]

17. Winther, B.; Gross, B.C.; Hendley, J.O.; Early, S.V. Location of bacterial biofilm in the mucus overlying the adenoid by light microscopy. Arch. Otolaryngol. Head Neck Surg. 2009, 135, 1239-1245. [CrossRef]

18. Kosikowska, U.; Korona-Głowniak, I.; Niedzielski, A.; Malm, A. Nasopharyngeal and Adenoid Colonization by Haemophilus influenzae and Haemophilus parainfluenzae in Children Undergoing Adenoidectomy and the Ability of Bacterial Isolates to Biofilm Production. Medicine 2015, 94, e799. [CrossRef] [PubMed] 
19. Tsou, Y.A.; Lin, C.D.; Hsu, H.Y.; Peng, M.T.; Kuo, Y.Y.; Tien, N.; Li, J.P.; Wang, C.K.; Wu, H.S.; Tsai, M.H.; et al. Association of $\beta$-Lactam-sensitive Haemophilus influenza Type B with adenoid biofilm formation in patients with adenoidectomy syrgery. Surg. Infect. 2015, 16, 709-715. [CrossRef] [PubMed]

20. Homøe, P.; Bjarnsholt, T.; Wessman, M.; Sørensen, H.C.; Johansen, H.K. Morphological evidence of biofilm formation in Greenlanders with chronic suppurative otitis media. Eur. Arch. Otorhinolaryngol. 2009, 266, 1533-1538. [CrossRef]

21. Zuliani, G.; Carlisle, M.; Duberstein, A.; Haupert, M.; Syamal, M.; Berk, R.; Du, W.; Coticchia, J. Biofilm density in the pediatric nasopharynx: Recurrent acute otitis media versus obstructive sleep apnea. Ann. Otol. Rhinol. Laryngol. 2009, 118, 519-524. [CrossRef]

22. Hoa, M.; Syamal, M.; Schaeffer, M.A.; Sachdeva, L.; Berk, R.; Coticchia, J. Biofilms and chronic otitis media: An initial exploration into the role of biofilms in the pathogenesis of chronic otitis media. Am. J. Otolaryngol. 2010, 31, 241-245. [CrossRef]

23. Saylam, G.; Tatar, E.C.; Tatar, I.; Ozdek, A.; Korkmaz, H. Association of adenoid surface biofilm formation and chronic otitis media with effusion. Arch. Otolaryngol. Head Neck Surg. 2010, 136, 550-555. [CrossRef]

24. Nistico, L.; Kreft, R.; Gieseke, A.; Coticchia, J.M.; Burrows, A.; Khampang, P.; Liu, Y.; Kerschner, J.E.; Post, J.C.; Lonergan, S.; et al. Adenoid reservoir for pathogenic biofilm bacteria. J. Clin. Microbiol. 2011, 49, 1411-1420. [CrossRef]

25. Daniel, M.; Imtiaz-Umer, S.; Fergie, N.; Birchall, J.P.; Bayston, R. Bacterial involvement in otitis media with effusion. Int. J. Pediatr. Otorhinolaryngol. 2012, 76, 1416-1422. [CrossRef]

26. Saafan, M.E.; Ibrahim, W.S.; Tomoum, M.O. Role of adenoid biofilm in chronic otitis media with effusion in children. Eur. Arch. Otorhinolaryngol. 2013, 270, 2417-2425. [CrossRef]

27. Thornton, R.B.; Wiertsema, S.P.; Kirkham, L.A.; Rigby, P.J.; Vijayasekaran, S.; Coates, H.L.; Richmond, P.C. Neutrophil extracellular traps and bacterial biofilms in middle ear effusion of children with recurrent acute otitis media-A potential treatment target. PLoS ONE 2013, 8, e53837. [CrossRef] [PubMed]

28. Szalmás, A.; Papp, Z.; Csomor, P.; Kónya, J.; Sziklai, I.; Szekanecz, Z.; Karosi, T. Microbiological profile of adenoid hypertrophy correlates to clinical diagnosis in children. Biomed. Res. Int. 2013, 2013, 629607. [CrossRef] [PubMed]

29. Van Hoecke, H.; De Paepe, A.S.; Lambert, E.; Van Belleghem, J.D.; Cools, P.; Van Simaey, L.; Deschaght, P.; Vaneechoutte, M.; Dhooge, I. Haemophilus influenzae biofilm formation in chronic otitis media with effusion. Eur. Arch. Otorhinolaryngol. 2016, 273, 3553-3560. [CrossRef]

30. Tawfik, S.A.; Ibrahim, A.A.; Talaat, I.M.; El-Alkamy, S.S.; Youssef, A. Role of bacterial biofilm in development of middle ear effusion. Eur. Arch. Otorhinolaryngol. 2016, 273, 4003-4009. [CrossRef]

31. de la Torre González, C.; Huante-Guido, M.; Velázquez Guadarrama, N.; Preciado, D.; Patiño López, G. Changes in biofilm in chronic cholesteatomatous otitis media in children following the application of sodium 2-mercaptoethanesulfonate (MESNA). Int. J. Pediatr. Otorhinolaryngol. 2018, 110, 48-52. [CrossRef] [PubMed]

32. Hoa, M.; Tomovic, S.; Nistico, L.; Hall-Stoodley, L.; Stoodley, P.; Sachdeva, L.; Berk, R.; Coticchia, J.M. Identification of adenoid biofilms with middle ear pathogens in otitis-prone children utilizing SEM and FISH. Int. J. Pediatr. Otorhinolaryngol. 2009, 73, 1242-1248. [CrossRef] [PubMed]

33. Galli, J.; Calò, L.; Giuliani, M.; Sergi, B.; Lucidi, D.; Meucci, D.; Bassotti, E.; Sanguinetti, M.; Paludetti, G. Biofilm's Role in Chronic Cholesteatomatous Otitis Media: A Pilot Study. Otolaryngol. Head Neck Surg. 2016, 154, 914-916. [CrossRef]

34. Wessman, M.; Bjarnsholt, T.; Eickhardt-Sørensen, S.R.; Johansen, H.K.; Homøe, P. Mucosal biofilm detection in chronic otitis media: A study of middle ear biopsies from Greenlandic patients. Eur. Arch. Otorhinolaryngol. 2015, 272, 1079-1085. [CrossRef]

35. Bakaletz, L.O. Bacterial biofilms in the upper airway-Evidence for role in pathology and implications for treatment of otitis media. Paediatr. Respir. Rev. 2012, 13, 154-159. [CrossRef]

36. Rayner, M.G.; Zhang, Y.; Gorry, M.C.; Chen, Y.; Post, J.C.; Ehrlich, G.D. Evidence of bacterial metabolic activity in culture-negative otitis media with effusion. JAMA 1998, 28, 296-299. [CrossRef]

37. Hall-Stoodley, L.; Hu, F.Z.; Gieseke, A.; Nistico, L.; Nguyen, D.; Hayes, J.; Forbes, M.; Greenberg, D.P.; Dice, B.; Burrows, A.; et al. Direct detection of bacterial biofilms on the middle-ear mucosa of children with chronic otitis media. JAMA 2006, 296, 202-211. [CrossRef] [PubMed]

38. Gu, X.; Keyoumu, Y.; Long, L.; Zhang, H. Detection of bacterial biofilms in different types of chronic otitis media. Eur. Arch. Otorhinolaryngol. 2014, 271, 2877-2883. [CrossRef] 
39. Saunders, J.; Murray, M.; Alleman, A. Biofilms in chronic suppurative otitis media and cholesteatoma: Scanning electron microscopy findings. Am. J. Otolaryngol. 2011, 32, 32-37. [CrossRef] [PubMed]

40. Moriyama, S.; Hotomi, M.; Shimada, J.; Billal, D.S.; Fujihara, K.; Yamanaka, N. Formation of biofilm by Haemophilus influenzae isolated from pediatric intractable otitis media. Auris Nasus Larynx 2009, 36, 525-531. [CrossRef]

41. Mizrahi, A.; Cohen, R.; Varon, E.; Bonacorsi, S.; Bechet, S.; Poyart, C.; Levy, C.; Raymond, J. Non typable-Haemophilus influenzae biofilm formation and acute otitis media. BMC Infect. Dis. 2014, 19, 400. [CrossRef] [PubMed]

42. Osgood, R.; Salamone, F.; Diaz, A.; Casey, J.R.; Bajorski, P.; Pichichero, M.E. Effect of pH and oxygen on biofilm formation in acute otitis media associated NTHi clinical isolates. Laryngoscope 2015, 125, 2204-2208. [CrossRef] [PubMed]

(C) 2019 by the authors. Licensee MDPI, Basel, Switzerland. This article is an open access article distributed under the terms and conditions of the Creative Commons Attribution (CC BY) license (http://creativecommons.org/licenses/by/4.0/). 